Ethiopian Journal of Environmental Studies \& Management 10(4): 492 - 504, 2017.

ISSN:1998-0507

doi: https://dx.doi.org/10.4314/ejesm.v10i4.7

Submitted: December 13, 2016

Accepted: May 26, 2017

\title{
RELATIONSHIP BETWEEN EXTREME DAILY RAINFALL AND MAXIMUM DAILY RIVER DISCHARGE WITHIN LAGOS METROPOLIS
}

\author{
*DUROWOJU, 0.S., ${ }^{1}$ OLUSOLA, A.0. ${ }^{1}$ AND ANIBABA, B.W. ${ }^{2}$ \\ ${ }^{1}$ Department of Geography, Osun State University, Osogbo, Nigeria \\ ${ }^{2}$ Department of Geography, University of Ibadan, Ibadan, Nigeria
}

\begin{abstract}
Many research works emphasized on rainfall pattern and urban flooding while others examined the relationship between extreme rainfall and its implication for flood frequency with little attempt to establish relationship between extreme rainfall and maximum river discharge. This study therefore, draws interconnection between extreme daily rainfall and maximum daily river discharge within Lagos metropolis. Data on rainfall were collected from Ikeja and Lagos Roof weather stations within the Yewa Basin in Lagos. Also, data on river discharge for Yewa River were obtained from Ogun-Oshun River Basin Development Authority, Abeokuta. Pearson Product Moment Correlation Coefficient (PPMC) was employed to assess the relationship between extreme daily rainfall and maximum daily river discharge at 95\% confidence level. Analysis of Variance (ANOVA) employed was used to test for the variability in the means of extreme daily rainfall events across the two weather stations.The result showed that there is a significant relationship between extreme daily rainfall events and maximum daily river discharge for Ikeja station ( $t_{\text {value }}=$ $2.60, C v=2.18, P \leq 0.05$ ) while no significant relationship was shown in Lagos Roof ( $t_{\text {value }}=$ 1.60, $C v=2.18, P \geq 0.05)$. It was also revealed that that there are no significant differences in the mean values of extreme daily rainfall across the stations $\left(F_{30}^{1}=2.086\right.$,

$P \geq 0.05)$.Therefore, this work has been able to show that the relationship between extreme rainfall and maximum river discharge is not always significant due to several factors such as distance from the sea (continentally) and variation in rainfall across the weather stations.
\end{abstract}

Key Words: Extreme Rainfall; Maximum River Discharge; Ogun-Osun, Flood Frequency

\section{Introduction}

Floods are recurrent phenomena in the world, resulting from a number of causes of which the most common cause is extreme rainfall (McEwen, 1989; Schecham and Hewitt 1969; Smith, 1996). Flood can be defined as the highest value of the stage or discharge of a stream during the water year (Gumbel, 1941; Cicioni, et al., 1972; Cunningham and Cunningham, 2008). Also Buchanan (1985) defined flood as "the inundation of a stretch of land by water as a result of temporary increase in the level of a river, 
lake burst, and other water bodies or by extreme rains or heavy downpours or when river overflows its channel".

Previous studies (Ayoade, 1976; Odekunle, 2001; Ologunorisa and Daigi, 2006; Durowoju, 2015) on extreme rainfall events in Nigeria have been able to look at its magnitude, frequency and distribution across several parts of the country. Also, studies on perception and adjustment to flooding in Nigerian cities have also engaged the attention of Ayoade and Akintola (1980), Oriola (1994), Ologunorisa (1999), Bekwe (1998), Muoghalu and Okonkwo (1998), Ologunorisa and Adeyemo (2005), among others. The effects of urban flooding in Lagos have been extensively studied and these include the works of Oyebande and Oguntoyinbo (1970), Adefolalu (1983), Ojo (1991), UNESCO (2008) and Odunuga (2008). Characteristics of rainstorm in Lagos have been studied by Ayoade and Akintola (1986). Vulnerability of poor urban coastal communities to flooding in Lagos also caught the attention of Adelekan (2010). Some of these research works emphasized on rainfall pattern and urban flooding while others examined the relationship between extreme rainfall and its implication for flood frequency with little attempt if any, to establish relationship between extreme rainfall and maximum river discharge which is the main focus of this paper.

Most coastal cities, such as Lagos experience high rate of urbanization, increase in general temperature, adjusted wind speed and pressure, high rate of evapotranspiration, and heavy cloud cover. These experiences make such cities vulnerable to extreme daily rainfall events as compared to other inland cities. It is on these notes that this study focuses on Lagos metropolis and draw interconnection between extreme daily rainfall and maximum daily river discharge.

\section{Study Area}

Lagos state lies approximately between longitudes $2^{\circ} 42^{\prime} \mathrm{E}$ and $3^{\circ} 42^{\prime} \mathrm{E}$ and latitude $6^{\circ} 22^{\prime} \mathrm{N}$ and $6^{\circ} 52^{\prime} \mathrm{N}$. The southern boundary of the state is formed by the $180 \mathrm{~km}$ long Atlantic coastline while its northern and eastern boundaries are shared with Ogun State. On the western side, the state is bordered by the Republic of Benin (Figure 1). 


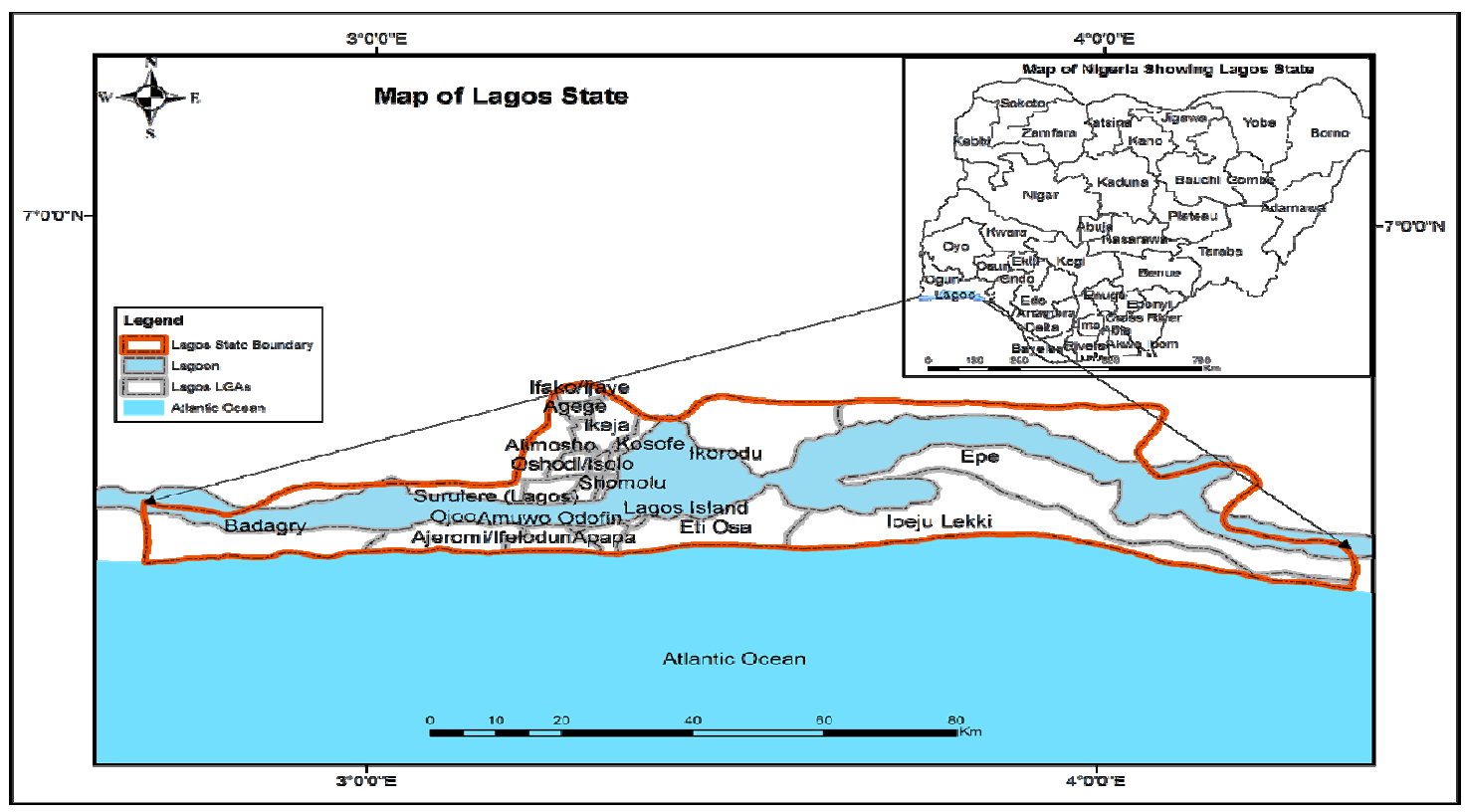

Fig. 1: Map of Lagos State

According to population data by National Population Commission (2007), Lagos State has a population of 9,013,534 people spread all across its 20 Local Government Areas. The average population density of Nigeria is about 152 persons per sq. $\mathrm{km}$ whereas Lagos has 2,695 persons per sq. $\mathrm{km}$ which is on the high side (http://www.lagosstate.gov.ng). The metropolitan area of Lagos has about $37 \%$ of the land area of Lagos state but over $80 \%$ of the population of the state resides in it (Ogunleye and Alo, 2010). Metropolitan Lagos constitutes about $33 \%$ of Lagos State, with 455 sq. km of the metropolis being water bodies, wetlands and mangrove swamps (Lagos State Ministry of Economic Planning and Budget, 2004). Lagos has grown spatially from a traditional core settlement of about $3.85 \mathrm{~km}^{2}$ in 1881 (Okude and Ademiluyi, 2006) to a metropolis of over $3,577.28 \mathrm{~km}^{2}$ in 2010 (Lagos State Government, 2014).

Lagos Metropolis originates from Islands separated by creeks that fringe the southwestern mouth of Lagos Lagoon and protected from the Atlantic Ocean by long sand spits such as the popular Bar Beach. The entire region lies within the coastal low land of south-western Nigeria and is less than $100 \mathrm{~m}$ above sea level (Figure 2). 


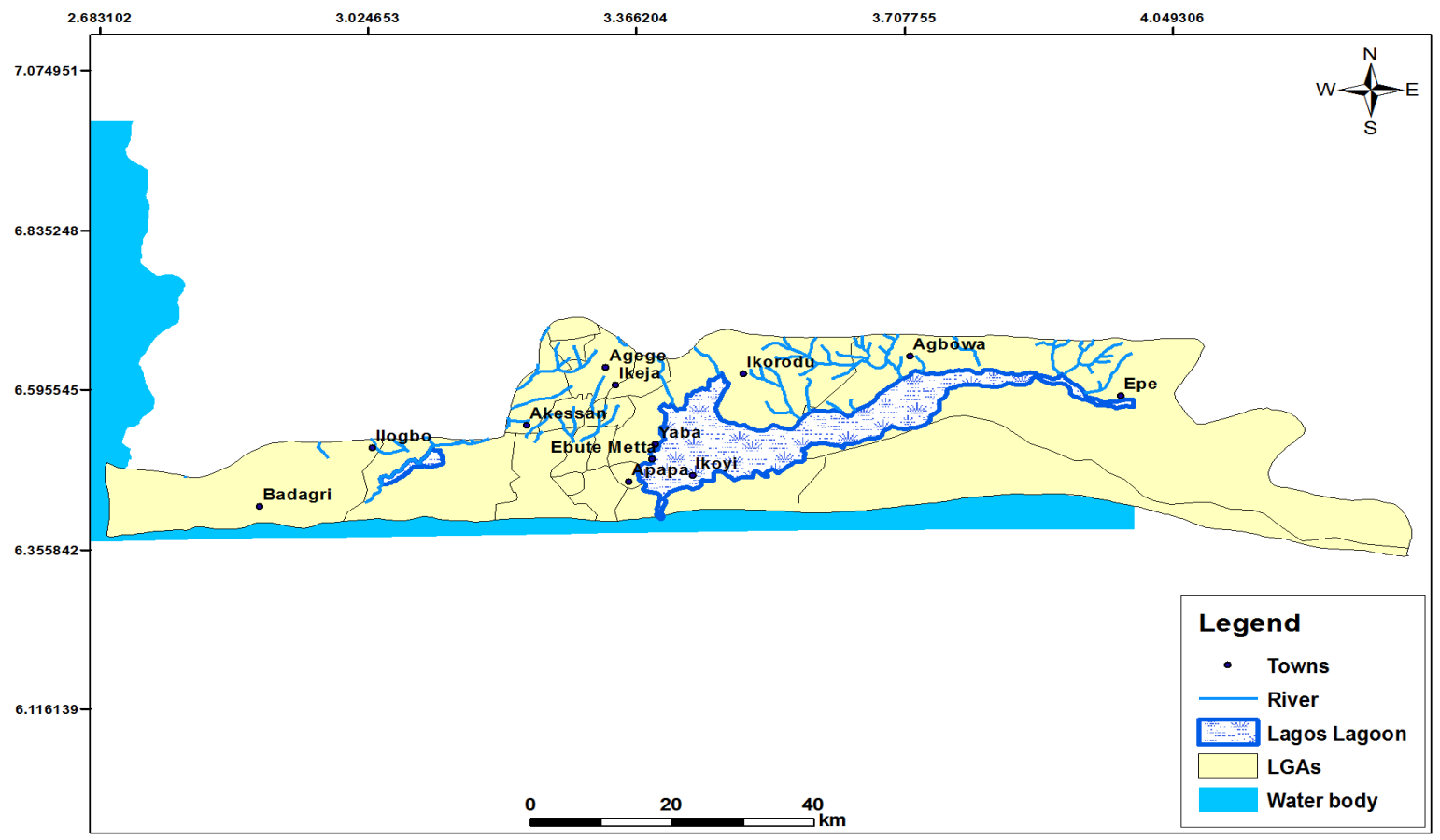

Fig. 2: Map of Lagos Metropolis showing its drainage network

\section{Methodology}

Rainfall data of two different weather stations (Ikeja and Lagos Roof) within the Yewa Basin in Lagos (Table 1) and data on river discharge were employed for assessing the level of relationship between extreme daily rainfall and maximum daily river discharge.

Table 1: Locational Characteristics of the Selected Weather Stations in Lagos metropolis

\begin{tabular}{lllll}
\hline Weather Station & Latitude & Longitude & Altitude $(\mathrm{m})$ & Data Record \\
\hline Ikeja & $06^{\circ} 35^{\prime} \mathrm{N}$ & $03^{\circ} 20 \mathrm{E}$ & 37.0 & $1984-2013$ \\
Lagos Roof & $06^{\circ} 27^{\prime} \mathrm{N}$ & $03^{\circ} 24^{4} \mathrm{E}$ & 14.0 & $1983-2012$ \\
\hline
\end{tabular}

Source: Nigerian Meteorological Agency (NIMET) Oshodi, Lagos

Gumbel Extreme Probability Theory was employed to analyze magnitudefrequency of extreme rainfall and maximum river discharge and use the relationship to predict the occurrence of flood in the study area.

Gumbel (1941) stated that for a data set whose distribution obeys the theory of extreme values, the mean must have a value that has a return period of 2.33 years for large sample like this study. The simpler method for determining whether a data set conforms to the theory of extreme is to plot it on the Extreme Probability Paper. If the data series conform, the values will lie on a more or less straight line when plotted on such paper. The graph obtained by drawing a line through the scatter of plotted values can then be used to find the return periods of specified values of the phenomenon under study and also to find the values that can be expected at specified return periods. Steps involved 
in determining the return period are stated as follows:

1. The observed rainfall and river discharge values are ranked in descending order of magnitude

2. The recurrence interval of each observation is computed using the formula: $\mathbf{T}=\frac{\mathbf{n + 1}}{m}$

3. Where $\mathbf{T}$ is the recurrence interval in years, $\boldsymbol{n}$ is the number of observations in the series and $\boldsymbol{m}$ is the rank of a particular observation.

4. The observed rainfall and river discharge values were then plotted against their computed recurrence intervals on the Extreme Value Probability Paper.

5. A line of fit is drawn on the scatter plots.

The concept of return periods is closely related to that of probability. It can be verified that the return period or recurrence interval of an event is inversely proportional to the probability (P) of that event occurring: $\mathbf{T}=\frac{\mathbf{1}}{\mathbf{P}} \cdot \mathbf{T}$ is return period or recurrence interval of an event and $\mathbf{P}$ is the probability of the event occurring. The probability $\left(\mathrm{P}_{\mathrm{T}}\right)$ that an event will occur within its stated return period $(\mathrm{T})$ is $\mathbf{P}_{\mathbf{T}}=\mathbf{1}-\left(\mathbf{1}-\frac{\mathbf{1}}{\mathbf{T}}\right)^{\mathbf{T}}$. The probability $\mathbf{P}_{\mathrm{T}}$ that an event with a return period of $\mathrm{T}$ years will occur within a particular $n$ year period is $\mathbf{P}_{\mathrm{T}}=\mathbf{1}$ $\left(1-\frac{1}{T}\right)^{\mathrm{n}}$.

To ascertain the relationship between extreme daily rainfall and maximum daily river discharge across the stations, Pearson Product Moment Correlation was performed and the decision tested at $95 \%$ level of confidence and to show the variation in analysis of Extreme Daily Rainfall across the two stations, Analysis of Variance (ANOVA) statistics was employed.

\section{Results and Discussion}

Extreme Daily Rainfall and Maximum Daily River Discharge

Table 2 shows the values of extreme daily rainfall together with their recurrence intervals and exceedence probabilities in Lagos. From Table 2, Ikeja Station for instance can be inferred that daily rainfall event of $237.3 \mathrm{~mm}$ which is the highest in the series can be expected to occur once in every 31 years with an exceedence probability of 0.03 . The result of Lagos-Roof Station revealed that the daily rainfall event of $280 \mathrm{~mm}$ which is the highest in the series can be expected to occur once in every 31 years with an exceedence probability of 0.03 . 
Table 2: Magnitude-Frequency of Extreme Daily Rainfall Events for the two stations

\begin{tabular}{llllllllll}
\hline \multicolumn{1}{l}{ IKEJA STATION } & \multicolumn{7}{l}{ LAGOS ROOF STATION } \\
\hline $\mathrm{N}$ & $\mathrm{R}$ & $\begin{array}{l}\text { EDR } \\
(\mathrm{mm})\end{array}$ & $\mathrm{T}$ & $\mathrm{EP}$ & $\mathrm{N}$ & $\mathrm{R}$ & $\begin{array}{l}\text { EDR } \\
(\mathrm{mm})\end{array}$ & $\mathrm{T}$ & $\mathrm{EP}$ \\
\hline 1997 & 1 & 237.3 & 31.00 & 0.03 & 2000 & 1 & 280 & 31.00 & 0.03 \\
2011 & 2 & 233 & 15.50 & 0.06 & 2011 & 2 & 278.4 & 15.50 & 0.06 \\
1990 & 3 & 169 & 10.33 & 0.10 & 1990 & 3 & 273.3 & 10.33 & 0.10 \\
2002 & 4 & 152.8 & 7.75 & 0.13 & 2004 & 4 & 237.7 & 7.75 & 0.13 \\
1987 & 5 & 147.2 & 6.20 & 0.16 & 2007 & 5 & 190.3 & 6.20 & 0.16 \\
2005 & 6 & 145.3 & 5.17 & 0.19 & 1988 & 6 & 183.8 & 5.17 & 0.19 \\
2000 & 7 & 140 & 4.43 & 0.23 & 2012 & 7 & 169.8 & 4.43 & 0.23 \\
1988 & 8 & 136.7 & 3.88 & 0.26 & 2005 & 8 & 169.7 & 3.88 & 0.26 \\
1991 & 9 & 133.8 & 3.44 & 0.29 & 1999 & 9 & 155.5 & 3.44 & 0.29 \\
1998 & 10 & 125.7 & 3.10 & 0.32 & 2003 & 10 & 150 & 3.10 & 0.32 \\
2004 & 11 & 123.8 & 2.82 & 0.35 & 2010 & 11 & 138.9 & 2.82 & 0.35 \\
2008 & 12 & 122.4 & 2.58 & 0.39 & 1998 & 12 & 133 & 2.58 & 0.39 \\
1984 & 13 & 119.5 & 2.38 & 0.42 & 2002 & 13 & 130.3 & 2.38 & 0.42 \\
2003 & 14 & 109.9 & 2.21 & 0.45 & 1993 & 14 & 126.2 & 2.21 & 0.45 \\
2009 & 15 & 108.4 & 2.07 & 0.48 & 1991 & 15 & 126.1 & 2.07 & 0.48 \\
1993 & 16 & 107.4 & 1.94 & 0.52 & 2006 & 16 & 125.3 & 1.94 & 0.52 \\
1999 & 17 & 96.5 & 1.82 & 0.55 & 1987 & 17 & 123.8 & 1.82 & 0.55 \\
1992 & 18.5 & 85.2 & 1.68 & 0.60 & 1989 & 18 & 123.3 & 1.72 & 0.58 \\
1995 & 18.5 & 85.2 & 1.68 & 0.60 & 1983 & 19 & 123.1 & 1.63 & 0.61 \\
2006 & 20 & 84 & 1.55 & 0.65 & 2001 & 20 & 114.6 & 1.55 & 0.65 \\
1989 & 21 & 80.2 & 1.48 & 0.68 & 1986 & 21 & 112.5 & 1.48 & 0.68 \\
1996 & 22 & 80.1 & 1.41 & 0.71 & 1995 & 22 & 107.7 & 1.41 & 0.71 \\
2010 & 23 & 78.5 & 1.35 & 0.74 & 1984 & 23 & 98.7 & 1.35 & 0.74 \\
1994 & 24 & 76.3 & 1.29 & 0.77 & 1996 & 24 & 96.7 & 1.29 & 0.77 \\
2007 & 25 & 76 & 1.24 & 0.81 & 1997 & 25 & 96 & 1.24 & 0.81 \\
2013 & 26 & 72.2 & 1.19 & 0.84 & 1994 & 26 & 89.9 & 1.19 & 0.84 \\
2001 & 27 & 67.1 & 1.15 & 0.87 & 2008 & 27 & 88.6 & 1.15 & 0.87 \\
2012 & 28 & 63.5 & 1.11 & 0.90 & 2009 & 28 & 77.5 & 1.11 & 0.90 \\
1986 & 29 & 58.2 & 1.07 & 0.94 & 1992 & 29 & 72.2 & 1.07 & 0.94 \\
1985 & 30 & 55.6 & 1.03 & 0.97 & 1985 & 30 & 66.2 & 1.03 & 0.97 \\
\hline & & & & & & & & &
\end{tabular}

$\boldsymbol{N}$ : Years; EDR: Extreme Rainfall Events; $\boldsymbol{T}$ : Return Interval; EP: Exceedence Probability 


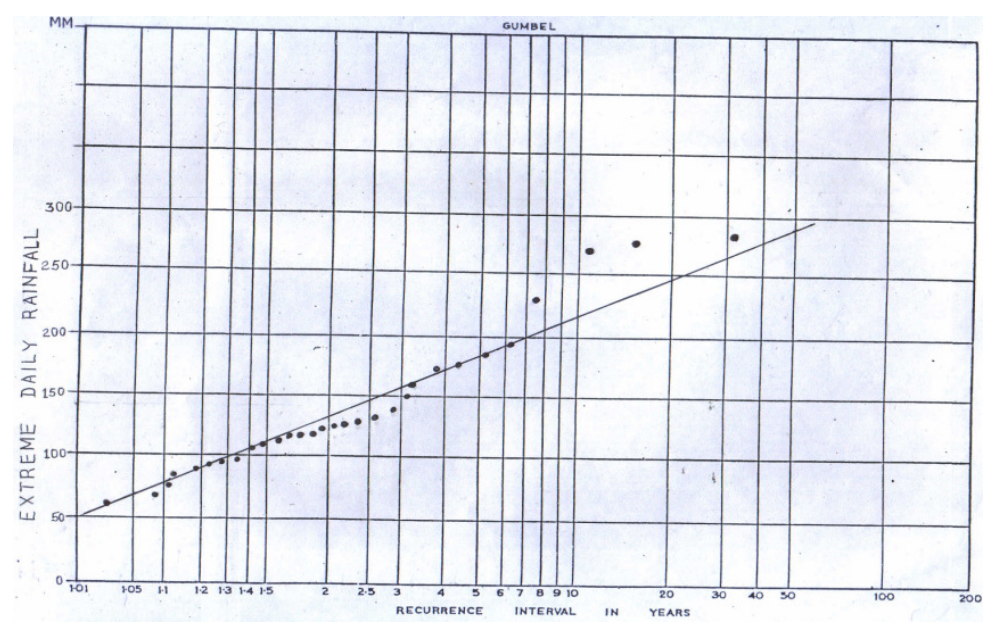

Fig. 3: Extreme Value Probability Graph for Ikeja

\section{Maximum Daily River Discharge}

The maximum daily discharge of $32.11 \mathrm{~m}^{3} \mathrm{~s}^{-1}$ which is the highest discharge in the series, can be expected to occur once in every 15 years with an exceedence probability of 0.07 while the

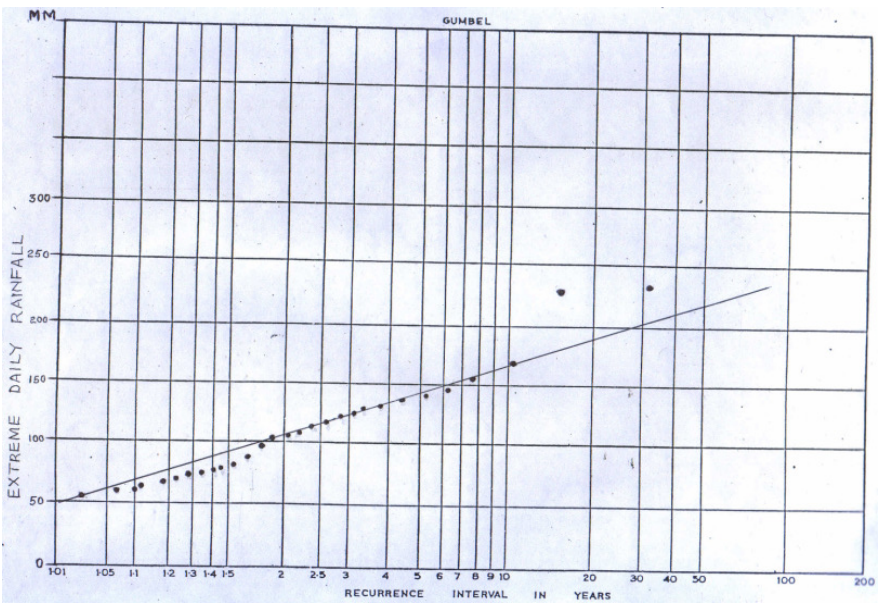

Fig. 4: Extreme Value Probability Graph for Lagos-Roof

maximum daily discharge of lesser magnitude in the series $0.3 \mathrm{~m}^{3} \mathrm{~s}^{-1}$, can be expected to occur once in every 1.07 years with an exceedence probability of 0.93 (Table 3).

Table 3: Magnitude-Frequency of Maximum Daily River Discharge of Yewa River, Ajilete, Lagos (1982-1995)

\begin{tabular}{lllll}
\hline Year & $\begin{array}{l}\text { Maximum Daily } \\
\text { Discharge }\left(\mathrm{m}^{3} \mathrm{~s}^{-1}\right)\end{array}$ & Rank & $\begin{array}{l}\text { Recurrence } \\
\text { Interval (Year) }\end{array}$ & $\begin{array}{l}\text { Exceedence } \\
\text { Probability }\end{array}$ \\
\hline 1987 & 32.11 & 1 & 15.00 & 0.07 \\
1982 & 11.4 & 2 & 7.50 & 0.13 \\
1989 & 10.85 & 3 & 5.00 & 0.20 \\
1988 & 9.75 & 4 & 3.75 & 0.27 \\
1995 & 4.8 & 5 & 3.00 & 0.33 \\
1984 & 3.96 & 6 & 2.50 & 0.40 \\
1990 & 3.8 & 7 & 2.14 & 0.47 \\
1992 & 2.55 & 8 & 1.88 & 0.53 \\
1991 & 2.2 & 9 & 1.67 & 0.60 \\
1985 & 1.7 & 10 & 1.50 & 0.67 \\
1993 & 0.76 & 11 & 1.36 & 0.73 \\
1986 & 0.49 & 12 & 1.25 & 0.80 \\
1983 & 0.42 & 13 & 1.15 & 0.87 \\
1994 & 0.3 & 14 & 1.07 & 0.93 \\
\hline
\end{tabular}




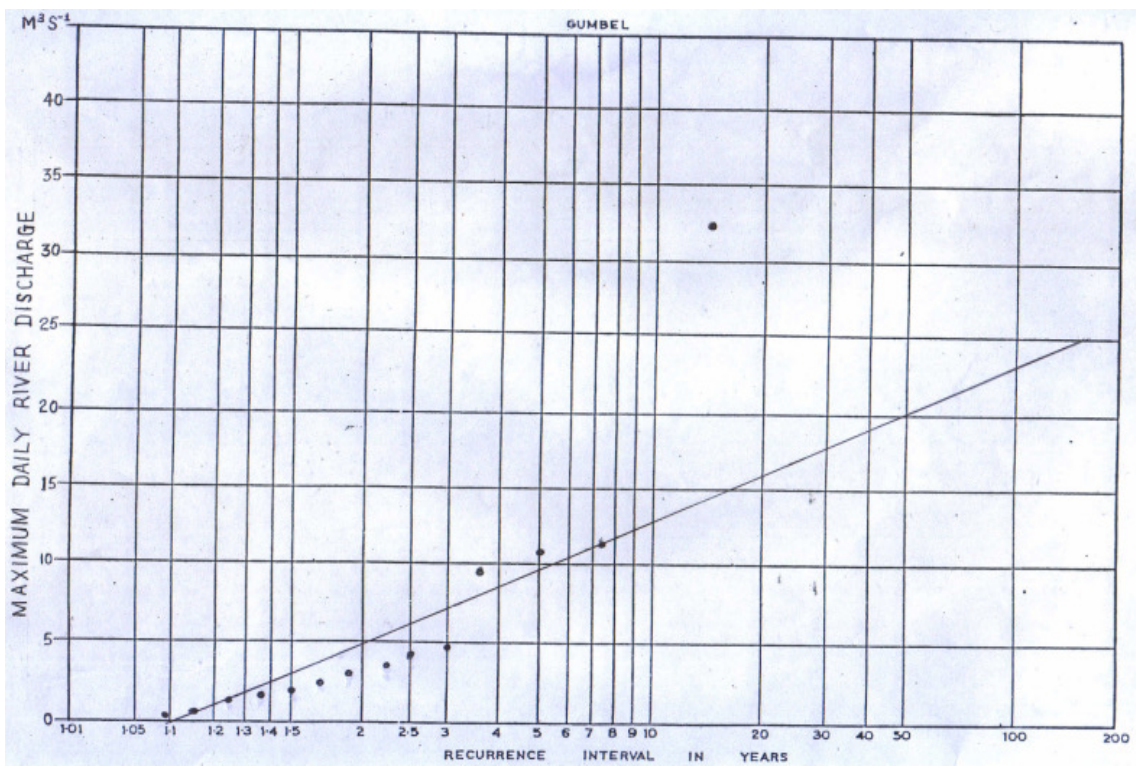

Fig. 5: Extreme Value Probability Graph for Maximum Daily River Discharge of Yewa River, Ajilete, Lagos

The extreme value probability graphs depict upward trends in the magnitudefrequency of extreme daily rainfall across the two stations and also in the value of maximum daily river discharge (Figs. 3, 4 and 5).

It was revealed from the study that most extreme falls correspond to major floods; the largest 24 hours rainfall on record of 20th September, 2000 with an estimated return period of 31 years likewise, the highly pronounced flood of 10th July, 2011 with an estimated return period of 15.5 years were associated with the flood occurrences. In the same vein, the maximum daily river discharge of 26th and 27th September, 1987 with an estimated return period of 15 years was also associated with the flood occurrences in the study area. Major floods were frequently associated with high recurrence interval storms greater than 20 years recurrence interval for 24 hours rainfall which provide enough intense, long duration rainfall to exceed soil moisture deficits and generate catastrophic runoff rates. The result of the return period analysis of extreme daily rainfall of varying magnitude in the study area has implication for the estimation of drainage design. This study throws more light on some basic calculations that could be carried out when designing for maximum drainage and flood control works or other hydraulic structures. In the study area, for instance, it would take about 2.07 years to equate or exceed an extreme daily rainfall amount of $109.9 \mathrm{~mm}$ and 1.07 years to exceed an extreme daily rainfall amount of $58.2 \mathrm{~mm}$ at Ikeja station. At Lagos-Roof station, it would take about 2.07 years to equate or exceed an extreme daily rainfall amount of $126.1 \mathrm{~mm}$ and about 1.07 years to exceed an extreme daily rainfall amount of $72.2 \mathrm{~mm}$. Furthermore, an average of 13-17 raindays is experienced in the study area during the severe flood month of June, majority of which occur as heavy rains. The negligence of these parameters 
for various designs in our urban drainages causes flooding and washing away of culverts such as seen in Ajegunle on Ikorodu Road, Agiliti, Maiden, Kiokio, Agboyin, Owode-Elede, Odo-
Ogun, Araromi and Magboro axis of Ogun State has been traced to incessant rainfall and a controversial release of water by the authorities of Oyan Dam.

Table 4: Correlation Coefficients between Extreme Daily Rainfall and Maximum Daily River Discharge

\begin{tabular}{lllllll}
\hline $\begin{array}{l}\text { Weather } \\
\text { Station }\end{array}$ & $\begin{array}{l}\text { Time } \\
\text { Period }\end{array}$ & $\begin{array}{l}\text { Correlation } \\
\text { Coefficient } \\
(\mathrm{r})\end{array}$ & $\begin{array}{l}\text { Coefficient of } \\
\text { Determination } \\
\left(\mathrm{r}^{2}\right)\end{array}$ & $\begin{array}{l}\text { Students } \\
\text { "t" value }\end{array}$ & Critical value Result \\
\hline Ikeja & $1982-1995$ & 0.60 & 0.36 & 2.60 & 2.18 & Significant \\
LagosRoof & $1982-1995$ & 0.37 & 0.14 & 1.60 & 2.18 & $\begin{array}{l}\text { Not } \\
\text { Significant }\end{array}$ \\
\hline
\end{tabular}

Table 4 reveals that relationship at Ikeja Station is significant while for Lagos Roof is not significant. The relationship between extreme daily rainfall and extreme daily discharge is expected to be significant (Zhang et al., 2005; Moberg et al., 2006; New et al., 2006) as revealed for Ikeja station. The non-significance of Lagos Roof may be attributed to the following factors such as variation in rainfall pattern across the two stations and continentality (Mudelsee et al., 2003; Klein et al., 2006; Su et al., 2006). The result therefore shows that the relationship between extreme daily rainfall and maximum daily discharge may not always be significant due to certain environmental factors.

\section{Spatial Analysis of Extreme Daily Rainfall}

Table 5: Analysis of Variance (ANOVA) of Extreme Daily Rainfall Events across the weather stations in Lagos Metropolis

\begin{tabular}{llllll}
\hline & Sum of & & & & Sig. \\
& Squares & df & Mean Square & F & .131 \\
\hline Between Groups & 13436.355 & 2 & 6718.178 & 2.086 & \\
Within Groups & 260823.295 & 81 & 3220.041 & & \\
Total & 274259.650 & 83 & & & \\
\hline
\end{tabular}

The spatial analysis carried out using ANOVA statistic revealed that there are no significant differences in the mean values of extreme daily rainfall across the stations. This showed that the magnitudes of extreme daily rainfall events are the same across the stations.

\section{Seasonality of Extreme Daily Rainfall (EDR) in Lagos}

Information on the seasonality of extreme daily rainfall is helpful in decision-making for setting catchment conditions antecedent to the storm (McEwen, 1989; Ologunorisa and Diagi, 2006; Wallis et al., 2007; Udosen, 2012). In this study, seasonality of EDR was calculated using frequency analysis (Tables 6 and 7).

The results of Ikeja station showed that the month of July has the highest frequency with 9 events; next to it in the series is June with a frequency of 8 and 
both with a total of $30 \%$ and $26.67 \%$ respectively (Table 6). Result from Table 7, Lagos-Roof station revealed that the month of June has the highest frequency of 13 with a total of $43.33 \%$ followed by July and October with frequency of 4 each and having a total of $13.33 \%$ respectively.

This implies that in most cases, the maximum daily rainfall in the varying

Table 6: Seasonality of Extreme Rainfall for Ikeja in Lagos

\begin{tabular}{lll}
\hline Month & Frequency & \% of Total \\
\hline April & 2 & 6.67 \\
May & 5 & 16.67 \\
June & 8 & 26.67 \\
July & 9 & 30.00 \\
September & 4 & 13.33 \\
October & 2 & 6.67 \\
Total & 30 & 100 \\
\hline
\end{tabular}

From the study, data on flood occurrence are presented for Lagos Metropolis and corroborated with available flood records for the study area. For example, the widespread flood that occurred in June 10, 1988 around LUTH, Ishaga was described as being very disastrous due to the aftermath of the flood that rendered over 300,000 people homeless with properties worth billions of naira wasted and also on Saturday, July 9, 1988, residents of Chief Natufe Street woke up to find themselves virtually in water. The particular flood year (1988) corresponds to the identified disastrous flood year in the study. The 10th July, 2011 corresponds to the date of extreme daily rainfall in the study area and it was recorded that the rain lasted for almost 24 hours which flooded areas like Agege, Egbeda, Jakande, Estate, Ojo, Ipaja-Ayobo, Igando, Orile, Ahmadu years under the study, were recorded in June with over $73 \%$ across the two stations. These events are expected to trigger flood events with different magnitudes, as June is mostly recognized as flood-season in most low-lying areas bordering coastal environments (Yang et al., 2010).

Table 7: Seasonality of Extreme Rainfall for Lagos-Roof station in Lagos

\begin{tabular}{lll}
\hline Month & Frequency & \% of Total \\
\hline Feb & 1 & 3.33 \\
April & 2 & 6.67 \\
May & 3 & 10 \\
June & 13 & 43.33 \\
July & 4 & 13.33 \\
September & 3 & 10 \\
October & 4 & 13.33 \\
Total & 30 & 100 \\
\hline
\end{tabular}

Bello Way, Apapa-Oshodi Expressway, Lagos-Badagary Expressway, Aboru, Owode, Meiran, Iju-Ishaga, Command and Ajegunle-Elede, parts of EtiOsa, among others, all in Lagos Metropolis.

\section{Conclusion}

This work has been able to show that the relationship between extreme rainfall and maximum river discharge is not always significant due to several factors such as distance from the sea (continentally) and variation in rainfall across the weather stations. The gumbel graphs show an upward trend and using existing flood records, it was revealed that major flood periods are associated with high recurrence interval storms greater than 20 years. Also, flood occurrence as presented for Lagos Metropolis has been shown to occur between June and July. Information as 
presented here will be very helpful in decision-making for setting catchment conditions. Also, for proper flood design structures across the state, it is important to understand the return interval in order to have sustained structures to produce liveable cities.

\section{References}

Adefolalu, D.O. (1983). Rainfall Pattern in the Coastal Areas of Nigeria. Nigeria Geographical Journal. 26(102): 153-170.

Adelekan, I.O. (2010). Vulnerability Assessment of an Urban Flood in Nigeria: Abeokuta Flood 2007. Springer Science+Business Media. Pp 1.

Ayoade, J.O. (1976). A Preliminary Study of the Magnitude, Frequency and Distribution of Intense Rainfall in Nigeria. Hydrological Sciences Bulletin, XXI: 419-426.

Ayoade, J.O. and Akintola, F.O. (1980). Public Perception of Flood Hazard in Two Nigerian Cities. Environment International.Vol. 4, pp 227-280.

Ayoade, J.O. and Akintola, F.O. (1986). Some Characteristics of Rainstorm in Lagos, Nigeria.Malaysian Journal of Tropical Geography, 15: 17-21.

Bekwe, W.F. (1998). Attitudes and Adjustments to Urban Flooding in Port Harcourt. Unpublished B.Sc. Dissertation, Rivers State College of Education, Port Harcourt.

Buchanan, R.O. (1985). Dictionary of Geography FEB. London.

Cicioni, G; Giullana, G. and Spazieni, F. M. (1972). Best Fitting of Probability Functions to a Set of Data for Flood Studies. In Floods and Droughts. Proceedings of the Second International Symposium in Hydrology at Colorado State University. Fort Collins, Colorado.

Cunningham, W.P. and Cunningham, M.A. (2008). Principles of Environmental Science Inquiry and Applications. $4^{\text {th }}$ (ed.). Published by McGraw Hill.

Durowoju, O.S. (2015). Analysis of Extreme Rainfall Events and their Implications for Flood Frequency in Lagos Metropolis. Unpublished M.Sc. Thesis, Department of Geography, University of Ibadan, Ibadan, Nigeria

Gumbel, E.J. (1941). The Return Period of Flood Flows. Annals of Mathematical Statistics, 12(2): 163190.

Klein, A.M.G., Peterson, T.C. and Quadir, D.A. (2006). Changes in Daily Temperature and Precipitation Extremes in Central and South Asia, J. Geophys. Res. 111: D16105, doi:10.1029/2005JD006316.

McEwen, L.J. (1989). Extreme Rainfall and Its Implication for Flood Frequency: A Case Study of the Middle River Tweed Basin, Scotland. Transactions of the Institute of British Geographers. 14(3): 287-298.

Moberg, A., Jones, P.D., Lister, D., Walther, A. and Brunet, M. (2006). Indices for Daily Temperature and Precipitation Extremes in Europe Analyzed for the Period 19012000. J. Geophys. Res. Vol. 111. D22106, doi:10.1029/2006JD007103.

Mudelsee, M., Borngen, M., Tetzlaff, G., and Grunewald, U. (2003). No 
Upward Trends in the Occurrence of Extreme Floods in Central Europe. Nature, 425: 166-169.

Muoghalu, L. N. and Okonkwo, A. U. (1998). Effects of Urban Flooding in Awka, Anambra States of Nigeria. Environmental Review, 2: 74-81.

National Population Commission (2007). Report of Nigeria's National Population Commission on the 2006 Census. Population and Development Review. Vol. 33, No. 1, pp. 206-210.

New, M., Hewitson, B., Stephenson, D. B. and Tsiga, A. (2006). Evidence of Trends in Daily Climate Extremes over Southern and West Africa. J. Geophys. Res. Vol. 111. D14102, doi: 10.1029/2005JD006289.

Odekunle, T.O. (2001). The MagnitudeFrequency Characteristics of Rainfall in Ondo. Southwestern Nigeria. Ife Research Publications in Geography. Vol. 8.Pp 36-41.

Odunuga, S. (2008). Urban Land Use Change and the Flooding Patterns in Ashimowu, Watershed Lagos, Nigeria.Ph.D. Thesis (unpl) University of Lagos, Akoka, Lagos, Nigeria.

Ogunleye, M. and Alo, B. (eds) (2010). State of the Environment Report Lagos 2010. Lagos: Ministry of Environment, Lagos State / Beachland Resources Limited.

Ojo, O. (1991). Rainfall Distribution and Flood Hazards in Lagos Metropolitan Area. Proceedings of International Symposium on Meteorological Hazards and Development held at Lagos and
Kano $23^{\text {rd }}$ September $-3^{\text {rd }}$ October, 1989, Pp. 182-189.

Okude, A.S., and Ademiluyi, I.A. (2006). Implications of the Changing Pattern of Land cover of the Lagos Coastal Area of Nigeria. AmericanEurasian Journal of Scientific Research, 1(1): 31 - 37.

Ologunorisa, E.T. (1999). Water Resource in Port Harcourt Region. Oyegun, C. U. and Adeyemo, A.A. (ed). Paragraphics, Port Harcourt. 69-80.

Ologunorisa, E.T. and Adeyemo, A. (2005). Public Perception of Flood Hazard in the Niger Delta, Nigeria. The Environmentalist. 25(10): 3545.

Ologunorisa, E.T. and Diagi, P.N. (2006). Extreme Rainfall and Its Implication for Flood Frequency in Western Niger Delta.A case study of Warri. Nigerian Journal for TropicalGeography, 1: 35-43.

Oriola, O. (1994). Strategies for Combating Urban Flooding in Developing Countries: A Case Study from Ondo. The Environmentalist, 14(1): 57-62.

Oyebande, B.L. and Oguntoyinbo, J.S. (1970). An Analysis of Rainfall Patterns in South Western States of Nigeria. Nigerian Geographica lJournal, 13(2): 141-162.

Schecham, L. and Hewitt, K. (1969). A Pilot Survey of Global Natural Disasters of the Past Twenty Years.Natural Hazard Research Working Paper No. 11, Department of Geography, University of Toronto.

Smith, K. (1996). Environmental Hazards. Routledge, London. 
Su, B.D., Jiang, T. and Jin, W.B. (2006). Recent Trends in Temperature and Precipitation Extremes in the Yangtze River Basin, China. Theor. Appl. Climatol., 83: 139-151.

Udosen, C.E. (2012). Rainfall Trends in Uyo-AkwaIbom State and Its implication on Urban Flooding. Journal of Engineering and Applied Sciences. 7(1): 79-85.

Wallis, J.R., Schaefer, M.G., Barker, B.L. and Taylor, G.H. (2007).Regional Precipitation-Frequency Analysis and Spatial Mapping for 24-hour and 2-hour Durations for Washington State. Hydrology and
Earth System Sciences. 11(1): 415442.

Yang, T., Shao, Q., Hao, Z., Chen, X., Zhang, Z., Xu, C., and Sun, L. (2010). Regional Frequency Analysis and Spatio-Temporal Pattern Characterization of Rainfall Extremes in the Pearl River Basin, China. Journal of Hydrology, 380: 386-405.

Zhang, Q., Jiang, T., Germmer, M. and Becker, S. (2005). Precipitation, Temperature and Discharge Analysis from 1951 to 2002 in the Yangtze River Basin, China. Hydrol. Sci. J. 50(1): 65-80. 